Second and third submaginal cells each receiving a recurrent nervure; first recurrent nervure in hind wings more than twice the length of the first transverse cubitus, the anal cell longly petiolated................ Opisthoneura, Ashm., n. g. (Type O. Crevecoeuri, Ashm.)

Costal transverse nervure interstitial with the apex of the basal nervure; third submarginal cell not twice as long as the first : claws simple ...........................

(Type H. laricis, Marl.)

Subfamily II.-Dineurine.

The petiolated lanceolate cell readily distinguishes this subfamily from the former. In general appearance the species included in it recall those to be found in the Blennocampince, the only marked structural difference being the renation in the front wings.

Only two genera are at present known, separated by the characters made use of in the following table :

\title{
Table of Genera.
}

Transverse radius oblique and joining the third submarginal cell beyond its middle; claws of hind legs with a small, subapical tooth.......................... Dineura, Dahlbom.

Transverse radius straight and interstitial with the second transverse cubitus, or very nearly, the latter itself being interstitial (or nearly) with the second recurrent nervure; claws bifid........ Mesoneura, Hartig.

\section{THE FREEZING OF INSECTS.}

BY HENRY H. LYMAN, MONTREAL.

In the 2 nd Report of the Entomological Society of Ontario, being that for $\mathrm{x} 89 \mathrm{I}$, there appeared a paper from my pen under the title "Can Insects Survive Freezing?"

I have recently come across further records of observations upon this subject, and deem them of sufficient interest to be republished in the Canadian Entomologist.

In looking over an interesting book of travels entitled "A Journey from Prince of Wales's Fort in Hudson's Bay to the Northern Ocean, undertaken by order of the Hudson's Bay Company for the discovery of 
copper mines, a north-west passage, etc., in the jears $1769,1770,177 \mathrm{I}$ and $177^{2}$, by Samuel Hearne," published in 1796 , I came across the following interesting notes on page 397 :

\section{"Frogs, Grubs, and Other Insects.}

"Frogs of various colours are numerous in those parts as far north as the latitude $6 \mathrm{I}^{\circ}$. They always frequent the margins of lakes, ponds, rivers and swamps; and, as the winter approaches, they burrow under the moss, at a considerable distance from the water, where they remain in a frozen state till the spring. I have frequently seen them dug up with the moss (when pitching tents in winter) frozen as hard as ice, in which state the legs are as easily broken off as a pipestem, without giving the least sensation to the animal; but by wrapping them up in warm skins, and exposing them to slow fire, they soon recover life, and the mutilated animal gains its usual activity; but if they are permitted to freeze again, they are past all recovery, and are never more known to come to life. The same may be said of the various species of spiders, and all the grub kind, which are very numerous in those parts. I have seen thousands of them dug up with the moss when we were pitching our tents in the winter, all of which were invariably enclosed in a thick web, which Nature teaches them to spin on those occasions; yet they were apparently all frozen as hard as ice. The spiders, if let fall from any height on a hard substance, would rebound like a gray pea; and all the grub kind are so hard frozen as to be as easily broken as a piece of ice of the same size; yet, when exposed to a slow heat, even in the depth of winter, they will soon come to life, and in a short time recover their usual motions."

In Dr. H. Guard Knaggs's Lepidopterist's Guide, on page 49 of the I 87 I edition, under the heading of "Ailments of Larvæ," I find the following:

"Frost Bite. It is well known that larvæ, which have been so stiffly frozen that they might have been easily broken, have afterwards recovered. The chief thing to be remembered in the treatment of such cases, is that the thawing should be effected very gradually-rapid thawing being dangerous," 